\title{
First record of Trichodina centrostrigeata Basson, Van As \& Paperna, 1983 (Ciliophora: Trichodinidae) from Oreochromis niloticus (Linnaeus, 1758) cultured in southeastern Mexico
}

\author{
María Amparo Rodríguez-Santiago ${ }^{1,2}$, Leticia García-Magaña ${ }^{3}$, Mayra I. Grano-Maldonado ${ }^{4}$ \\ Enrique N. Silva-Martínez ${ }^{5}$, Jesús Guerra-Santos ${ }^{5} \&$ Rolando Gelabert $^{5}$ \\ ${ }^{1}$ Consejo Nacional de Ciencia y Tecnología (CONACyT), México \\ ${ }^{2}$ Facultad de Ciencias Naturales, Centro de Investigación de Ciencias Ambientales \\ Universidad Autónoma del Carmen, Campeche, México \\ ${ }^{3}$ División Académica de Ciencias Biológicas Villahermosa \\ Universidad Juárez Autónoma de Tabasco, Tabasco, México \\ ${ }^{4}$ Universidad Autónoma de Occidente, Mazatlán, Sinaloa, México \\ ${ }^{5}$ Facultad de Ciencias Naturales, Centro de Investigaciones en Ciencias Ambientales \\ Universidad Autónoma del Carmen, Ciudad del Carmen, Campeche, México \\ Corresponding author: María Amparo Rodríguez-Santiago (arodriguez@ pampano.unacar.mx)
}

\begin{abstract}
Nile tilapia Oreochromis niloticus is one of the most economically important freshwater fish cultivated worldwide. Despite its importance and being one of the cichlid fish most studied from a parasitological point of view in Mexico, there are few studies about the ectoparasite protozoa that infect them. In this study, a total of 240 juvenile individuals of $O$. niloticus from an experimental culture (in Tabasco, Mexico) were examined to detect the presence of trichodinid parasites. Trichodinid parasites were impregnated with silver nitrate and stained with Harris' hematoxylin solution for taxonomic evaluation. A disc-shaped trichodinid with a body diameter of $38 \pm 3.3 \mu \mathrm{m}$ adhesive disc diameter of $34 \pm 3.3 \mu \mathrm{m}$ and a denticulate ring diameter of $19 \pm 2.1 \mu \mathrm{m}$ was found. Trichodina centrostrigeata has been previously reported having specificity for cypriniform species, but in the present study, the Nile tilapia was reported as a new fish host and southeastern Mexico as a new geographical distribution for this parasite.
\end{abstract}

Keywords: Trichodina; Ciliophora; ciliated protozoa; ectoparasite; tilapia; Mexico

Ciliated protozoa of the genus Trichodina are one of the most common ectoparasites of both freshwater and marine fishes. These parasites are capable in some cases of inflicting significant damage to their hosts with resultant mortalities. Despite the threat they pose in other regions of the world, in Mexico, there are few studies (Rodríguez-Santiago, 2002). The study of parasites as pathogenic agents for host fish is important in the ingrowth processes, in particular in aquaculture conditions. Infestation in fish increases when they are cultured intensively since high density causes an increase in the parasite populations, which may cause an epizootic mainly in the case of parasites of a direct cycle such as certain protozoans (Woo, 1999). Trichodinids, known for their frequency and negative effects, have been found as parasites especially in weakfish in overpopulated conditions in supply pools with low oxygen environments (Snieszko \& Axelrod, 1971). Cichlids and carps are commonly affected by trichodinids which cause "epizootic" buds with great economic losses in cultures (Paperna, 1996). The larval stages of fish are the most sensitive to the development of protozoan diseases, including trichodiniasis. Clinical signs of trichondiniasis consist of an increase of the quantity of white mucus, fin raveling, lethargy, anorexia, scale loss and tendency to group near the water entrances. The fish present skin hyperemia and when the gills are involved it may cause asphyxia. The problem is more complicated when there are secondary infections, bringing as a consequence bacteria diseases, together constituting a set of considerable processes in the fish pathology. Trichodina centrostrigeata Basson, Van As \& Paperna, 1983 (Basson et al., 1983), among other ciliated parasites, are natives from Asia or Africa 


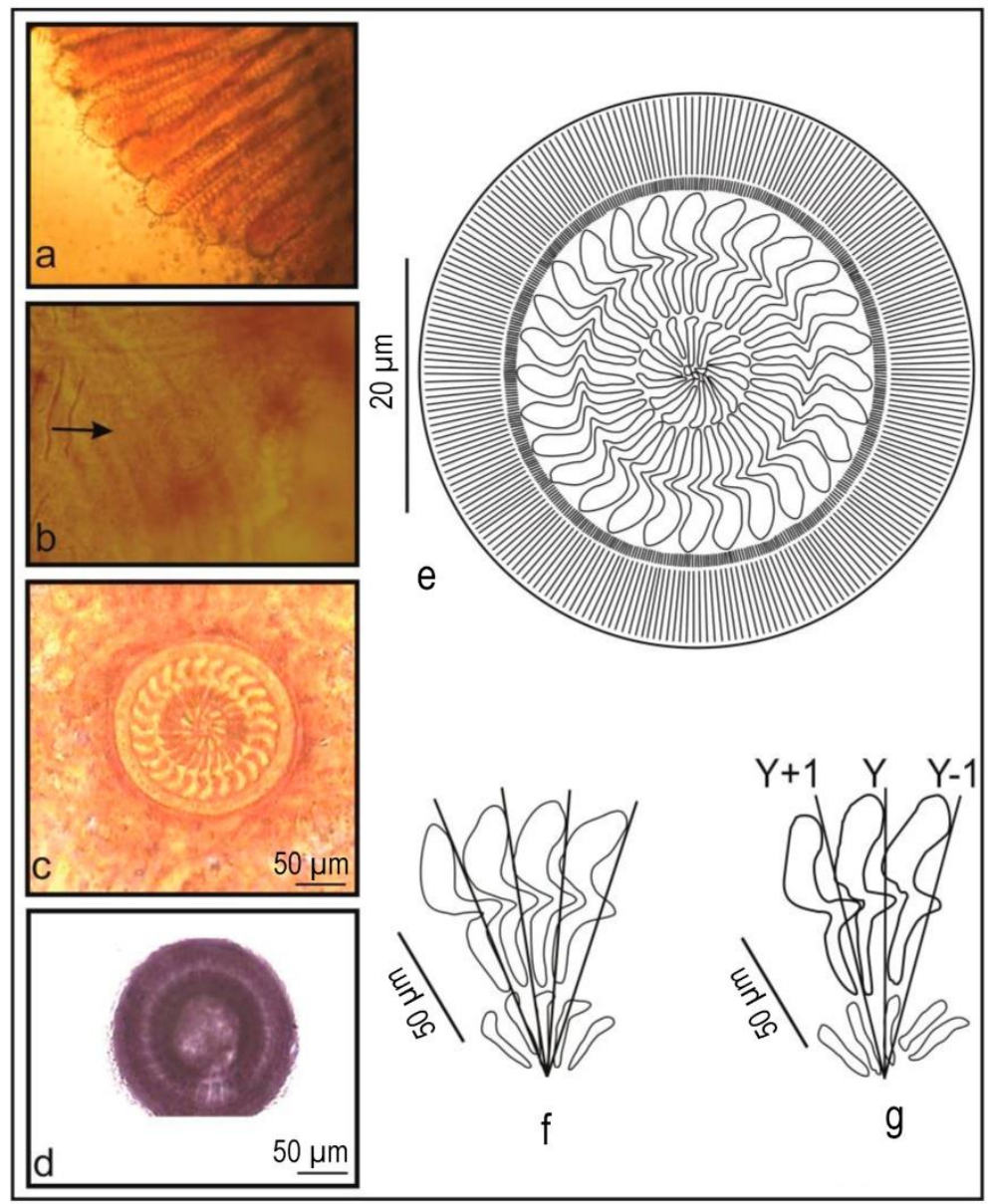

Figure 1. a) Trichodinids in a fresh-mounted smear from the gill arches, b) parasite Trichodina centrostrigeata in differential interference employing a contrast microscope, c) adhesive disc of parasite in silver nitrate impregnation, d) Ehrlich's acid hematoxylin stained nuclear apparatus of parasite, e) drawing of parasite whole body diagrammatic drawings of denticles, f-g) parasite of Nile tilapia from the present study, d) parasite of Nile tilapia of South Africa (Van As \& Basson, 1984).

but have been disseminated to many localities worldwide (Rodríguez-Santiago, 2002). Understanding Oreochromis niloticus in cultured freshwater fish is central to the aquaculture industry in Mexico, which ranks $28^{\text {th }}$ in the world with a production of $143,747 \mathrm{t}$ of freshwater species (FAO, 2005, 2012, 2013).

In this study, we report a new geographic location in the southeastern region of Mexico for $T$. centrostrigeata parasitizing the skin, fins, and gills of $O$. niloticus, previously identified for T. niloticus from southern Africa (Basson et al., 1983). Nile tilapia is cultured at high densities in fish farms in southeastern Mexico, Villahermosa (Tabasco). Fish showed characteristic disease signs: rubbing on the sides or bottom on the pond, caudal fin erosion, hemorrhagic areas in the skin (Valladão et al., 2013, 2014, 2015, 2016), abundant slime and corneal opacity (29\%). Smears of trichodinids were taken from the skin and gills of 240 infested $O$. niloticus fingerlings and juveniles. The silvery stain by Klein (1958) was used for detailed observation of the denticle structures, the fixation disk characteristics and the number of their constituents, and the Harris' hematoxylin solution was used for the observation of the nuclear apparatus as additional information. The methodology reported by Lom (1958) and Wellborn (1967) was used for taxonomic identification. Once the tinted slides were mounted through the technique by Klein (1958), they were observed in detail under the optical microscope (Motic BA310E) searching for trichodinids (Fig. 1). Those that were completely mature and well-shaped with all the constituents of the adhesive disk clear and well tinted were selected. At a 1000x amplification, the denticle morphology of each one of the organisms was carefully 
Table 1. Comparative measurements $(\mu \mathrm{m})$ of Trichodina centrostrigeata taken from Oreochromis niloticus (Basson et al., 1983), O. mossambicus, Tilapia rendalli, Pseudocrenilabrus philander, T. sparrmanii (Basson \& Van As, 1994) and $O$. niloticus Egyptian variety (Rodríguez-Santiago, 2002). Rp/d: number of radial pins per denticle, Med: macronucleu external diameter. Numbers represent the absolute minimum, and maximum values observed. The average \pm SD (standard deviation) is indicated within parenthesis. The number located after SD indicates the quantity of trichodinid specimens that were measured.

\begin{tabular}{lcccc}
\hline & $\begin{array}{c}\text { Basson } \text { et al. (1983) } \\
\text { Oreochromis niloticus }\end{array}$ & $\begin{array}{c}\text { Basson \& Van As (1994) } \\
\text { Cichlids and cyprinid }\end{array}$ & $\begin{array}{c}\text { Rodríguez-Santiago (2002) } \\
\text { Oreochromis niloticus } \\
\text { Egyptian variety }\end{array}$ & $\begin{array}{c}\text { This study } \\
\text { Oreochromis niloticus }\end{array}$ \\
\hline Position on host & Skin and fins & Skin and fins & Skin and fins & Skin and fins \\
Locality & South Africa & South Africa, Philippines & Sinaloa, Mexico & Villahermosa, Mexico \\
Body diameter & $31.2-45.8(37.6 \pm 3.6,100)$ & $30.0-45.0(36.0 \pm 4.2,16)$ & $30-44(37.51 \pm 3.9,31)$ & $30-43(36.0 \pm 4.2,25)$ \\
Adhesive disc diameter & $18.7-33.3(23.2 \pm 2.5,100)$ & $18.5-26.0(21.7 \pm 2.4,16)$ & $18-38(19.64 \pm 2.1,31)$ & $18-25.0(21.7 \pm 2.4,25)$ \\
Central rods & $12-16(14,100)$ & $13-16(14,12)$ & $12-15(13,31)$ & $12-16(13,25)$ \\
Number of denticles & $26-30(28,100)$ & $24-29(26,16)$ & $23-29(26,31)$ & $20-29(26,25)$ \\
Rp/d & $6-7(7,100)$ & $7-8(8,7)$ & $6-8(6,31)$ & $7-8(7,25)$ \\
Denticle lengh & $2.0-6.2(4.1 \pm 0.6,100)$ & $3.0-5.0(4.3 \pm 0.6,13)$ & $3.3-5.6(4.29 \pm 0.74,31)$ & $3-5.5(4.1 \pm 0.6,25)$ \\
Blade lengh & $2.8-6.4(5.2 \pm 0.7,100)$ & $5.0-6.0(5.5 \pm 0.5,15)$ & $3.3-6.7(4.55 \pm 0.77,31)$ & $5.0-6.5(5.5 \pm 0.5,25)$ \\
Ray lengh & $1.13 .0(1.9 \pm 0.3,100)$ & $1.0-1.5(1.1 \pm 0.2,15)$ & $2.22-6.7(2.73 \pm 0.89,31)$ & $1.0-1.5(1.1 \pm 0.3,25)$ \\
Lightning length & $3.2-6.0(4.5 \pm 0.6,100)$ & $3.5-5.0(4.3 \pm 0.6,15)$ & $3.3-7.8(5.29 \pm 0.97,31)$ & $3-5.0(4 \pm 0.6,20,25)$ \\
Med & $20.9-49.7(37.6 \pm 6.9,23)$ & --- & $19-37(32 \pm 7.4,7,13)$ & -- \\
\hline
\end{tabular}

observed: blade and ray, the degree of silvery impregnation of the center of the adhesive disk and presence or absence of chitin structures, etc. The angle described by the adoral spiral was also observed. All of these characteristics were compared to the descriptions by Lom \& Dyková (1992) to locate them taxonomically in a tentative way, and this was followed by the review of the original studies for the determination of the species, for which the corresponding measurements were also done. The specific differentiation was based on a description for trichodinids as ectoparasites of cichlids and cyprinid fishes in South Africa and Israel (Basson et al., 1983). Trichodinids were counted using an optical microscope (Motic BA310E) at 60x and 100x magnification (Rodríguez-Santiago, 2002). Although T. centrostigeata was documented in $T$. nilotica in northwestern Mexico by RodríguezSantiago (2002), this information was never formally published. The ectoparasite species found was identified as Trichodina centrostrigeata, which constitutes the first record for Mexico. The morphologic characteristics that led to its identification were: wide triangular denticle blades with blunt edges, a straight thorn rod-like shape and a curving slightly backward about the blade (Fig. 1). The morphometric charac-teristics of $T$. centrostrigeata are shown in Table 1. The taxonomical characteristics considered were: wide triangular denticle blades with blunt edges, a straight thorn rod-like shape and a curving slightly backward about the blade.

\section{ACKNOWLEDGMENTS}

Thanks for the support during the elaboration process of this work to Lety Sanchez. We also thank Dr. Rafael Martínez García, M.C. Serapio López Jiménez, M.C. Alejandro McDonald Vera and M.C. Miguel Angel Pérez Méndez for the time dedicated to the review of this work and for comments. In the same way, we thank Guadalupe García Jiménez, Luisa Ramos Colorado and Guadalupe Reyes for their support in the laboratory analysis, and to the Tropical Aquaculture Laboratory of the division for their support in the collections of the organisms (UJAT). We are grateful to Karen Englander (Faculty of Languages, University of Baja California) for her English review and editing of the manuscript. Special thanks to the anonymous reviewers for their comments to improve this article.

\section{REFERENCES}

Basson, L. \& Van As, J.G. 1994. Trichodinids ectoparasites (Ciliophora: Peritrichida) of wild and cultured fresh-water fishes in Taiwan, with notes on their origin. Systematic Parasitology, 28: 197-222.

Basson, L., Van As, J.G. \& Paperna, I. 1983. Trichodinid ectoparasites of cichlids and cyprinid fishes in South Africa and Israel. Systematic Parasitology, 5: 245-257.

Klein, B.M. 1958. The dry silver method and its proper use. The Journal of Protozoology, 5: 99-103. 
Lom, J. 1958. A contribution to the systematic and morphology of endoparasitic trichodinids from amphibians, with a proposal of uniform specific characteristics. Journal of Parasitology, 5: 251-263.

Lom, J. \& Dykova, I. 1992. Protozoan parasites of fishes. Elsevier, Amsterdam.

Organización para la Alimentación y la Agricultura (FAO). 2012. El estado mundial de la pesca y la acuicultura. Organización de las Naciones Unidas para la Alimentación y la Agricultura, Roma, 251 pp.

Organización para la Alimentación y la Agricultura (FAO). 2005-2013. Cultured aquatic species information programme Oreochromis niloticus. Programa de información de especies acuáticas. Departamento de Pesca y Acuicultura de la FAO. [http://www.fao.org/ fishery/ culturedspecies/Oreochromis_niloticus/es]. Revie-wed: 20 January 2018.

Paperna, I. 1996. Parasites, infections, and diseases of fishes in Africa. Food and Agriculture Organization, CIFA Technical Paper, 31: 220 pp.

Rodríguez-Santiago, M.A. 2002. Identificación de especies ectoparásitas del género Trichodina (Ciliophora: Peritrichida) en Tilapia nilotica mediante correlación invariante con filtros compuestos. Tesis de Maestría en Ciencias, Unidad Mazatlán en Acuicultura y Manejo Ambiental, Sinaloa, 112 pp.

Sniezko, S.F. \& Axelrod, H. 1971. The prevention and treatment of diseases of warm water fishers under subtropical conditions, with particular emphasis on intensive fish farming. Laboratory for Research of Fish Diseases Nir-David, Israel, 3: 40-57.

Received: 20 February 2018; Accepted: 25 October 2018
Valladão, G.M.R., Alves, L.O. \& Pilarski, F. 2016. Trichodiniasis in Nile tilapia hatcheries: diagnosis, parasite: host-stage relationship and treatment. Aquaculture, 451: 444-450.

Valladão, G.M.R., Gallani, S.U. \& Pilarski, F. 2015. Phytotherapy as an alternative for treating fish disease. Journal of Veterinary Pharmacology and Therapeutics, 38: 417-428.

Valladão, G.M.R., Gallani, S.U., Pádua, S.B., Martins, M.L. \& Pilarski, F. 2014. Trichodna heterodentata (Ciliophora) infestation on Prochilodus lineatus larvae: a host-parasite relationship study. Parasitology, 141: 662-669.

Valladão, G.M.R., Pádua, S.B., Gallani, S.U., MenezesFilho, R.N., Dias-Neto, J., Martins, M.L. \& Pilarski, F. 2013. Paratrichodina africana (Ciliophora): a pathogenic gill parasite in farmed Nile tilapia. Veterinary Parasitology, 197: 705-710.

Van As, J.G. \& Basson, L. 1984. Checklist of freshwater fish parasites from southern Africa. South African Journal of Wildlife Research, 14: 49-61.

Wellborn, T.L. 1967. Trichodina (Ciliata: Urceolariidae) of freshwater fishes of the South Eastern United States. Journal of Protozoology, 14: 399-412.

Woo, P.T.K. 1999. Fish diseases and disorders. Protozoan and metazoan infections. CABI Publishing, Oxfordshire, pp. 229-262. 